\title{
THE EFFICACY OF LIQUIDATION AND BANKRUPTCY PREDICTION MODELS FOR ASSESSING GOING CONCERN
}

\author{
Nirosh Kuruppu \\ Fawzi Laswad \\ Peter Oyelere
}

May 2002

Centre of Accounting Education and Research PO Box 84 Lincoln University CANTERBURY

Telephone No: (64) (3) 3253627

Fax No: (64) (3) 3253847

E-Mail: laswad@lincoln.ac.nz

ISSN 1174-5045

ISBN 1-877176-74-5 


\begin{abstract}
Although previous research generally find bankruptcy prediction models to outperform auditors' going concern opinion accuracy in identifying failing companies, recent research questions whether bankruptcy is the best proxy for assessing going concern since filing for bankruptcy is not synonymous with the invalidity of the going concern assumption. Furthermore, in contrast to debtor-oriented countries such as the US, liquidation is the most likely outcome of corporate insolvency in creditor-oriented countries such as the UK, Germany, Australia and New Zealand. This suggests that bankruptcy prediction models have limited use for assessing going concern in creditor-oriented countries. Previous research has not recognised this distinction between corporate bankruptcy and liquidation in developing statistical models as an audit tool for assessing going concern. This study examines the efficacy of a corporate liquidation model and a benchmark bankruptcy prediction model for assessing company liquidation. It finds that the liquidation model is more accurate in predicting company liquidations in comparison with the benchmark bankruptcy prediction model. Most importantly, Type 1 errors for the liquidation prediction model is significantly lower than for the bankruptcy prediction model, which indicates its greater efficacy as an analytical tool for assessing going concern. The results also suggest that bankruptcy prediction models may not be appropriate for assessing going concern in countries where the insolvency code is creditor-oriented.
\end{abstract}

Keywords: Going concern, Auditors' opinions, Analytical techniques, Corporate liquidation prediction, Corporate bankruptcy prediction, Insolvency frameworks. 


\section{Contents}

List of Tables

1. Introduction 1

2. The Going Concern Concept in Auditing 2

3. The Relevance of Statistical Models for Assessing Going Concern 4

3.1 Introduction 4

3.2 Review of Empirical Findings $\quad 6$

4. Research Objective and Hypotheses $\quad 8$

5. $\quad$ Research Design 9

5.1 Sample Selection and Variables 9

5.2 Statistical Modelling Approach 11

5.3 Model Validation and Hypotheses Testing 12

6. Data Analysis $\quad 12$

$\begin{array}{lll}6.1 & \text { The Model } & 12\end{array}$

6.2 Altman's Z-score Model 14

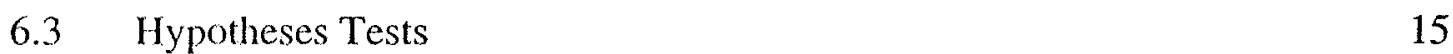

7. Summary and Conclusions 16

$\begin{array}{ll}\text { References } & 18\end{array}$ 


\section{List of Tables}

1. Evaluation Required by Auditing Standards on Going Concern 3

2. Studies Applying Bankruptcy Prediction Models for Assessing Going Concern 7

$\begin{array}{ll}\text { 3. Discriminant Function Summary Statistics } & 13\end{array}$

4. Lachenbruch Classification Results $\quad 14$

5. Altman's Z-score Model Accuracy $\quad 14$ 


\section{Introduction}

The purpose of this article is to examine the efficacy of statistical corporate liquidation prediction models for assessing client going concern status. Previous research shows that statistical bankruptcy prediction models consistently outperform auditors' going concern judgement in discriminating between bankrupt and non-bankrupt companies (Levitan and Knoblett, 1985; Cormier et al., 1995; Grant et al., 1998). However, research also questions whether corporate bankruptcy is the best proxy for the assessment of going concern since filing for bankruptcy is not synonymous with the invalidity of the going concern assumption (Shultz, 1995; Casterella et al., 2000).

Indeed, in countries such as the US where the insolvency laws are debtor oriented, corporate bankruptcy procedures encourage companies in financial difficulty to continue as going concerns (Franks et al., 1996). Therefore it is possible for companies that file for bankruptcy to reorganise and emerge from bankruptcy, or to merge with another entity as a going concern (Shultz, 1995). This is in contrast to the insolvency procedures in creditor oriented countries such as the UK, Germany, Australia and New Zealand where liquidation is the most common outcome of corporate insolvency (Kaiser, 1996; Franks et al., 1996). The costs of corporate liquidation also exceed the cost of bankruptcy to shareholders and to other stakeholders (Alderson and Betker, 1996; Alderson and Betker, 1999). Moreover, companies in debtor oriented countries may also choose to file for bankruptcy for strategic reasons other than financial distress, such as to avoid an unprofitable contract (Kennedy and Shaw, 1991; Chatterjee et al., 1996; Franks et al., 1996). These arguments suggest that a bankruptcy prediction model might not be the best proxy for assessing going concern.

This study examines the efficacy of a statistical model to predict company liquidation, which is a better proxy for assessing the validity of the going concern assumption than bankruptcy prediction models used in previous research. Given the differences in debtor and creditororiented insolvency frameworks, the results can assist auditors in choosing appropriate business failure prediction models as an analytical technique for assessing going concern.

The study develops a liquidation prediction model from a sample of 135 NZSE listed companies and analyses its classification accuracy in terms of Type 1 and Type 2 errors, and compares it to a benchmark bankruptcy prediction model which has been used to benchmark the performance of newly developed corporate failure models. The results indicate that the 
Type 1 errors for the liquidation prediction model are significantly lower than for the bankruptcy prediction model. Given the high costs associated with misclassifying failing companies, it suggests that the liquidation prediction model can be used as a valuable audit tool for assessing going concern. The high accuracy of the liquidation prediction model also raises the implications of using bankruptcy prediction models in countries where the insolvency framework is creditor-oriented.

The remainder of the article is structured as follows. Section 2 examines the importance of the going concern concept in auditing and the requirements of the current auditing standards on going concern. Section 3 examines the usefulness of corporate distress models as an analytical procedure for assessing going concern, and discusses prior research in the area. Section 4 describes the research objective and hypotheses, followed by a description of the research design in Section 5. The data analysis and results are presented in Section 6, while Section 7 concludes the paper with the main findings and opportunities for further research.

\section{The Going Concern Concept in Auditing}

The going concern assumption has been recognised as one of the main concepts underlying financial reporting, which justifies accounting practices such as period reporting, accrual accounting and asset valuation (Boritz and Kralitz, 1987; Barnes and Huan, 1993; IAS 570). The going concern concept assumes that the reporting entity will continue in operation for the foreseeable future, and that it will be able to realise assets and discharge financial obligations in the normal course of operations. If the going concern assumption were to become invalid, both the period reporting and accrual concepts will also lose their relevance since defining assets as future economic benefits then becomes erroneous (Boritz and Kralitz, 1987). The traditional valuation of assets also loses its relevance since the realisation of assets at their reported value in the balance sheet becomes uncertain (Boritz and Kralitz, 1987). Furthermore, the classification of assets and liabilities into current and non-current categories in the balance sheet would also become meaningless.

Even though the going concern assumption is a fundamental concept in financial reporting, there has been little professional guidance on assessing going concern prior to the issuance of SAS 34 in the United States in 1981 (Johnson and Khurana, 1993; Guy and Carmichael, 2000). The dissatisfaction with auditors over the many company failures that occurred soon 
after the issuance of a clean audit report motivated the development of SAS 34. The aim of this auditing standard was to bridge the publics' expectation gap that auditors should be held responsible for disclosing going concern uncertainties (Guy and Carmichael, 2000). Other countries have since then followed suit to issue their own auditing standards on going concern such as SAS 130 in the UK, AUS 708 in Australia and AS 520 in New Zealand (Loftus and Miller, 2000).

Auditing standards on going concern including SAS 34 only require a passive approach to assessing going concern (Asare, 1990). For instance, it was only when matters indicating going concern issues were detected during the course of an audit that the auditor was required to search for more evidence supporting or refuting the going concern assumption. Subsequent revisions of auditing standards on going concern have increased in scope to minimise the 'expectations gap' between the financial statement users and auditors (Geiger et al., 1998). Current auditing standards on going concern now require the auditor to actively seek out circumstances that may negate the validity of the going concern assumption. Table 1 summarises the main requirements of auditing standards on going concern in the US, UK, Australia, New Zealand and international auditing standards.

Table 1

Evaluation Required by Auditing Standards on Going Concern

\begin{tabular}{|c|c|c|c|}
\hline Country & Standard & Evaluation required & Audit period \\
\hline US & $\begin{array}{l}\text { SAS } 59 \text { (SAS } 34 \text { was } \\
\text { superseded by SAS 59) }\end{array}$ & $\begin{array}{l}\text { Specifically form an opinion on the } \\
\text { going concern assumption from the } \\
\text { results of usual audit procedures. }\end{array}$ & $\begin{array}{l}\text { Not to exceed one year from } \\
\text { the date of the financial } \\
\text { statements being audited }\end{array}$ \\
\hline UK & SAS 130 & $\begin{array}{l}\text { Plan and perform procedures } \\
\text { specifically designed to identify going } \\
\text { concern uncertainties (s21) }\end{array}$ & $\begin{array}{l}\text { Not specifically defined or } \\
\text { elaborated (s9), but likely to } \\
\text { be the period that management } \\
\text { has considered in assessing } \\
\text { going concern s21[ii]). }\end{array}$ \\
\hline Australia & AUS 708 & $\begin{array}{l}\text { Auditor must obtain evidence that the } \\
\text { going concern assumption is } \\
\text { appropriate (s10) } \\
\text { Must specifically assess going } \\
\text { concern problems as part of the audit } \\
\text { planning process (s.17) }\end{array}$ & One year $(s 4)$ \\
\hline New Zealand & AS 520 & $\begin{array}{l}\text { Obtain audit evidence that the going } \\
\text { concern assumption is appropriate } \\
\text { (s27). } \\
\text { Plan and perform specific procedures } \\
\text { to identify going concern } \\
\text { uncertainties }(\mathrm{s} 8 \mathrm{a}, 30)\end{array}$ & One year (s25) \\
\hline IAS (IFAC) & ISA 570 & $\begin{array}{l}\text { Auditor should consider the } \\
\text { appropriateness of } \\
\text { the going concern assumption when } \\
\text { planning and performing audit } \\
\text { procedures and in evaluating their } \\
\text { results }(s 2, s 11, s 12, s 17)\end{array}$ & One year $(s 18, s 19)$ \\
\hline
\end{tabular}


Table 1 shows that auditors are required to perform procedures designed specifically to identify going concern uncertainties. Furthermore, since the use of analytical procedures is mandatory in all the countries referred to above, for example SAS 56, AUS 512 and AS 504, auditing standards are already in place to accommodate statistical models as an integral part of the review process.

\section{The Relevance of Statistical Models for Assessing Going Concern}

\subsection{Introduction}

The interest in statistical models for assessing going concern is largely motivated by the perceived expectations gap between auditors and financial statement users that place greater responsibility on the auditor for disclosing going concern uncertainties (Asare, 1990). The potential usefulness of statistical models for assessing going concern is recognised in the expectations gap literature since the late 1970s, when the Cohen commission's report (1978) on auditor responsibilities first suggested their use as a means toward reducing the expectations gap (Altman, 1983; Levitan and Knoblett, 1985; Asare, 1990). More recently, the AICPA (1993) in the US has also recognised the public's demand for an early warning system of corporate failure (Loftus and Miller, 2000). Given the success of statistical models in discriminating between failed and non-failed companies, they are seen as a tool that could assist auditors in making more accurate going concern judgements (Levitan and Knoblett, 1985; Louwers, 1998).

Previous research show objective statistical models to outperform auditors in assessing company failure (Cormier et al., 1995; Grant et al., 1998). One of the best known is Altman's ZETA bankruptcy prediction model which is used by over 80 commercial clients (Loftus and Miller, 2000). Such models can help auditors in forming more accurate assessments of clients' going concern status, and thereby help reduce the costs associated with inappropriate audit opinions such as litigation from shareholders, loss of clients and the loss of professional reputation (Koh, 1991; Carcello and Palmrose, 1994, Grant et al., 1995).

Koh and Brown (1991) assert that an accurate corporate distress model can help the auditor identify high-risk companies in the planning stages of the audit. This helps the auditor in 
planning specific audit procedures aimed at assessing the appropriateness of the going concern assumption (Koh and Brown, 1991). Statistical models developed from Probit and Logit analyses, which are types of conditional probability model, also provide an objective assessment of the probability of the client failing. A high probability of failure alerts the auditor to the need to apply a more rigorous audit assessment than he or she might have in the absence of this information.

In the final stages of the audit, a corporate distress model can be used to verify that the overall audit opinion in relation to going concern is appropriate for the client's financial statements (Chen and Church, 1992). In the event that an adverse or qualified opinion is rendered, an objective statistical model can more readily help the auditor in justifying the decision to interested parties (Koh and Oliga, 1990; Chen and Church, 1992).

Furthermore, statistical evidence is accepted as evidence in court (Evidence Amendment Act No.2 1980, NZ). This allows an objective model to be used as a defence in court cases claiming audit failure (Wallace, 1983). A model that can assist auditors in minimising the risk of client misclassification can lessen the risks of litigation, which might subsequently filter down to clients in the form of lower audit fees. In the United States, for example, approximately $9 \%$ of auditor revenues are spent on defending lawsuits (Grant et al., 1998).

Due to the usefulness of statistical corporate failure models described above, auditing standards such as in Australia already recognise statistical models. The Australian standard on analytical procedures (AUS 512) with reference to AUS 708 on Going Concern draws the auditors' attention to financial models developed from Probit and Discriminant Analysis for assessing going concern. The Proceedings of the Expectations Gap Roundtable in the United States (1993) has also called for continued research into the effectiveness of analytical procedures, and it has identified the use of bankruptcy prediction models for assessing the validity of the going concern assumption (Blocher and Loebbecke, 1993). The ability of corporate failure models to provide objective evidence for making a going concern judgement is also recognised by accounting practitioners (Constable and Woodliff, 1994). 


\subsection{Review of Empiricall Findings}

Considerable empirical research compares the accuracy of bankruptcy prediction models to auditors' going concern qualifications. The seminal work by Altman and McGough (1974) investigates the usefulness of bankruptcy prediction models for assessing company going concern status, and follows the pioneering work of Beaver (1966) and Altman (1968). Altman and McGough (1974) find that their model was 82 percent successful in predicting bankruptcy filings when compared with auditors' going concern assessment of 46 percent accuracy. These results were re-affirmed in a later study by Altman (1983) where the models' average success in predicting bankruptcy was 86 percent compared to auditors' 48 percent.

Table 2 provides a summary of empirical studies. Most of the studies that followed the early work of Altman and McGough (1974) are similar in design, except that they were applied to different samples and sample periods, and examined bankrupt companies. These include Levitan and Knoblett (1985), Mutchler (1985), Koh and Killough (1990), Koh and Brown (1991) and Cormier et al., (1995) who developed bankruptcy prediction models to predict company failure. ${ }^{1}$ The developed models were found to be more accurate when compared with auditors' prior audit opinions.

\footnotetext{
${ }^{1}$ The most common definition of company failure used in prior accounting research is filing for bankruptcy. Other definitions of corporate failure used in accounting research include large losses disproportionate to assets, stock exchange delisting, companies in the process of liquidation or receivership, an arrangement with creditors, failure to pay annual listing fees, negative stock returns and the receipt of a going concern qualification (Mutchler, 1985; Cormier et al., 1995; Zhang and Hartold, 1997; Nasir et al., 2000).
} 
Table 2

Studies Applving Bankruptcy Prediction Models for Assessing Going Concern

\begin{tabular}{|c|c|c|c|c|c|c|}
\hline Study & Place & Sample & $\begin{array}{c}\text { Definition of } \\
\text { Company Failure }\end{array}$ & Method & Findings & Conclusions \\
\hline $\begin{array}{l}\text { Altman and McGough } \\
\text { (1974) }\end{array}$ & US & $\begin{array}{l}33 \text { bankrupt; } 33 \text { non-bankrupt } \\
\text { companies }\end{array}$ & Bankruptcy & MDA & $\begin{array}{l}\text { Model accuracy } 82 \% \text { compared } \\
\text { to auditors } 46 \% \text { accuracy. }\end{array}$ & $\begin{array}{l}\text { Bankruptcy predictions models can } \\
\text { be useful to auditors. }\end{array}$ \\
\hline Altman (1983) & US & 40 failed companies & Bankruptcy & $\mathrm{MDA}$ & $\begin{array}{l}\text { Average bankruptcy model } \\
\text { accuracy } 86.2 \% \text { compared to } \\
\text { auditors' } 48.1 \% \text { accuracy. }\end{array}$ & $\begin{array}{l}\text { Auditors should examine analytical } \\
\text { methods which can assist in the } \\
\text { going concern context. }\end{array}$ \\
\hline $\begin{array}{l}\text { Levitan and Knoblett } \\
\text { (1985) }\end{array}$ & US & $\begin{array}{l}32 \text { failed; } 32 \text { non-failed } \\
\text { companies }\end{array}$ & Bankruptcy & $\mathrm{MDA}$ & $\begin{array}{l}\text { One year prior to bankruptcy, } \\
\text { model } 84 \% \text { accurate compared } \\
\text { to auditors' } 66 \% \text { accuracy. } \\
\text { Three year model average is } \\
67 \% \text { compared to auditors' } 33 \% \text {. }\end{array}$ & $\begin{array}{l}\text { Model accuracy is a better predictor } \\
\text { of bankruptcy when compared to } \\
\text { auditors' opinion. }\end{array}$ \\
\hline Mutchler (1985) & US & $\begin{array}{l}119 \text { going concern qualified; } \\
119 \text { non-going concern } \\
\text { modified companies }\end{array}$ & $\begin{array}{l}\text { Receipt of going } \\
\text { concern qualification }\end{array}$ & $\mathrm{MDA}$ & $\begin{array}{l}\text { Model was able to predict the } \\
\text { GC opinion } 83 \% \text { of the time. }\end{array}$ & $\begin{array}{l}\text { Urges more studies into the overall } \\
\text { function of the audit opinion since } \\
\text { the majority of these opinions could } \\
\text { be predicted by publicly available } \\
\text { information. }\end{array}$ \\
\hline $\begin{array}{l}\text { Koh and Killough } \\
\text { (1990) }\end{array}$ & US & $\begin{array}{l}35 \text { failed; } 35 \text { non-failed } \\
\text { companies }\end{array}$ & $\begin{array}{l}\text { Companies reported as } \\
\text { "failed" by the Wall } \\
\text { Street Journal Index. No } \\
\text { further details are } \\
\text { provided }\end{array}$ & $\mathrm{MDA}$ & $\begin{array}{l}\text { Model and auditors have similar } \\
\text { accuracy for non-failed } \\
\text { companies }(88.6 \% \text { and } 88.86 \% \\
\text { respectively). } \\
\text { Model accuracy strongly } \\
\text { outperforms auditors for failed } \\
\text { companies ( } 78.57 \% \text { to only } \\
21.43 \% \text { by auditors). }\end{array}$ & $\begin{array}{l}\text { Asserts that future research could } \\
\text { provide auditors with more } \\
\text { sophisticated and accurate models } \\
\text { for assessing going concern } \\
\text { problems. }\end{array}$ \\
\hline $\begin{array}{l}\text { Koh and Brown } \\
\text { (1991) }\end{array}$ & US & $\begin{array}{l}40 \text { failed; } 40 \text { non-failed } \\
\text { companies }\end{array}$ & Bankruptcy & Probit & $\begin{array}{l}\text { Model predicted } 82.50 \% \text { of non- } \\
\text { going concerns and } 100 \% \text { of } \\
\text { going concerns yielding an } \\
\text { average success rate of } 91.25 \% \text {. } \\
\text { Auditors' average success rate } \\
\text { was } 68.75 \% \text {, with a } 40 \% \text { success } \\
\text { rate for failed companies. }\end{array}$ & $\begin{array}{l}\text { Suggests the model as a useful audit } \\
\text { tool. }\end{array}$ \\
\hline Cormier et al., (1995) & Canada & $\begin{array}{l}138 \text { failed; } 112 \text { non-failed } \\
\text { companies }\end{array}$ & $\begin{array}{l}\text { Annual stock return less } \\
\text { than } \\
-50 \%\end{array}$ & $\begin{array}{l}\text { Logit, MDA } \\
\text { and Recursive } \\
\text { Partitioning } \\
\text { (RP) }\end{array}$ & $\begin{array}{l}\text { Classification rates for failed } \\
\text { companies using Logit, MDA } \\
\text { and RP respectively: } \\
76.08 \%, 81.88 \%, 70.3 \% \\
\text { Auditors' accuracy was not } \\
\text { compared in this study. }\end{array}$ & $\begin{array}{l}\text { Models developed in this study can } \\
\text { be compared with current practice in } \\
\text { accounting firms. From this exercise, } \\
\text { better specified models can be } \\
\text { developed. }\end{array}$ \\
\hline
\end{tabular}


The findings of the empirical studies summarised in Table 2 indicate that statistical models could assist auditors in forming more accurate going concern judgements. This would assist the accounting profession in reducing the public's expectations gap of the profession, and in increasing the public's confidence in the audit function.

However, even though prior research have found bankruptcy prediction models to be useful for assessing going concern, other research indicate that a bankrupt company can be regarded as a going concern until the resolution of bankruptcy, and that company bankruptcy is less costly compared to company liquidation (Shultz, 1995; Alderson and Betker, 1996; Franks et al., 1996; Casterella et al., 2000). Indeed, Alderson and Betker (1996) show that the loss of going concern value forms the largest component of liquidation cost at 32 percent of corporate value. Furthermore, more than 50 percent of companies that re-emerge from bankruptcy generate a return that exceeds the return available on benchmark portfolios, indicating that corporate bankruptcy is not as costly as liquidation to shareholders and to other stakeholders (Alderson and Betker, 1996; Alderson and Betker, 1999).

These findings suggests that inappropriate audit opinions issued to liquidated companies are more costly than inappropriate opinions issued to companies which emerge from bankruptcy as going concerns. This distinction between bankrupt and liquidated companies suggests that company liquidation is a better proxy for assessing client's going concern status in statistical business continuity models.

\section{Research Objective and Hypotheses}

The objective of this study, therefore, is to examine the efficacy of a business continuity model to predict company liquidation. It is argued that liquidation is the better proxy for assessing the validity of the going concern assumption than bankruptcy prediction models used in previous research. To achieve this objective, three hypotheses are tested.

$\mathbf{H}_{1}:$ A liquidation prediction model outperforms a bankruptcy prediction model in discriminating between liquidated and continuing companies.

This hypothesis examines whether a liquidation prediction model is a better predictor of company liquidation than a benchmark bankruptcy prediction model. Altman's Z-score 
bankruptcy prediction model is used for the comparison since it is frequently used to benchmark the performance of newly developed bankruptcy prediction models (Holmen, 1988; Eidleman, 1995). Furthermore, it is a tried and tested model that has been used in a number of different countries across various industry settings, and it has been even found to outperform country specific corporate failure models (Holmen, 1988; Eidleman, 1995).

$H_{2}:$ Type 1 errors are lower for the liquidation prediction model compared to the bankruptcy prediction model in discriminating between liquidated and continuing companies.

A Type 1 error is misclassifying a failed company as non-failed. Prior research indicates that Type 1 errors are costliest to auditors, where it would lead to the possible loss of audit fee, professional reputation and litigation from shareholders (Koh, 1991; Carcello and Palmrose, 1994; Geiger et al., 1998). This indicates that for a corporate failure model to be an effective analytical technique for assessing going concern, it has to be highly accurate in predicting failing companies. This hypothesis identifies the errors of misclassifying a failed company as a non-failed company for the developed liquidation prediction model and the bankruptcy prediction model.

$\mathbf{H}_{3}$ : Type 2 errors are lower for the liquidation prediction model compared to the bankruptcy prediction model in discriminating between liquidated and continuing companies.

A Type 2 error is misclassifying a healthy company as failed, and the costs of Type 2 errors include the loss of professional reputation, loss of audit fee, and the client's demise due to the inappropriate audit opinion (Geiger et al., 1998; Louwers et al., 1999) This hypothesis assesses the difference in accuracy between the liquidation prediction model and the bankruptcy prediction model in misclassifying non-failed companies. The next section describes the research design followed to test the above hypotheses.

\subsection{Research Design}

\subsection{Sample Selection and Variables}

The first stage in testing the developed hypotheses requires the development of a liquidation prediction model for New Zealand companies. Most of prior studies on bankruptcy prediction were able to use online databases such as Compact Disclosure and NAARS to obtain the 
required data for model development. New Zealand has no such online database of failed company financial data which make the data collection much more difficult.

However, a large number of listed companies failed in the years following the stock market crash of 1987 which enables the researcher to obtain a sufficiently large number of failed companies. Therefore, to enable the development of a liquidation prediction model for $\mathrm{New}$ Zealand, listed companies that were liquidated and struck off from the Companies Register from 1987-1993 were identified from the Companies Office database. This process identified 85 liquidated companies. A further group of 50 continuing companies that delisted during the same period were also selected to represent companies which are going concerns, but which are not in sound financial health (Zhang and Harrold, 1997; Nazir et al., 2000). Since auditors are more likely to issue a going concern qualification to companies in financial stress, a model that can discriminate between failed and other stressed companies is argued to be especially useful (Foster et al., 1998). Companies in the financial and property sectors were excluded from the sample due to significant industry differences (Grant el al., 1998). This resulted in a total sample size of 135 companies, which is a significantly large sample relative to the number of companies listed on the New Zealand Stock Exchange.

The financial statement data were then manually obtained from the various archives of New Zealand universities and national libraries. For each company, 174 individual pieces of data were entered, which resulted in over 23,000 entries.

The financial statement data collated from the sample companies were used to calculate 63 explanatory variables for the prediction model. This includes variables found to be useful used in prior studies and additional variables not used in prior corporate failure studies. The new variables were identified as potentially useful variables for corporate failure prediction by examining the literature on financial statement analysis (Ketz et al., 1990; Woelfel, 1994; Bertoneche and Knight, 2001). These new variables include ratios calculated from total tangible assets, interest coverage, working capital turnover, asset turnover ratios and the audit report lag, among others. The dependent variable was coded as a binary variable, where 1 is defined as a failure and 0 is defined as a non-failure. 


\subsection{Statistical Modelling Approach}

Multiple Discriminant Analysis (MDA) is used to develop the liquidation prediction model since it is proven to be robust in bankruptcy prediction and there is no significant difference in accuracy between MDA models and Logit/Probit Analyses (Collins and Green, 1982; Allen and Chung, 1998). Furthermore, preliminary data analysis using both these methods on the New Zealand sample identified the MDA model as having greater accuracy in predicting company liquidation when compared to a Logit model developed from the same data.

Prior studies using Multiple Discriminant Analysis (MDA) have often used a sample matching approach, for example, by matching failed and non-failed companies by industry. However, this approach is not necessary since discriminant analysis optimally classifies between the two given sample groups. Lau (1987) and Gilbert et al. (1990) have used this approach. Furthermore, due to the relatively small New Zealand sample size compared to overseas studies it is difficult to obtain a sufficiently large number of failed companies if sample matching is used.

Prior studies have also used equal group sizes when analysing the discriminant function that maximally discriminates between the two groups. However, discriminant analysis does not require equal group sizes since prior probabilities can be computed from the individual samples by weighing (George and Mallery, 2001). Hence in this study, prior probabilities of group membership are calculated from the failed and non-failed sample sizes.

The discriminant function is derived by the Wilks' lambda $(\lambda)$ stepwise method. This procedure uses the 63 variables for the 135 companies in an iterative process to retain the most significant variables in a discriminant function that maximally discriminates between the two sample groups by minimising the Wilks' $\lambda$ at each step of variable entry. The stepwise procedure is used in preference to a 'forced entry' approach because in practice, the stepwise discriminant procedure performs better than when all the variables are forced into the discriminant function (George and Mallery, 2001). This was confirmed during preliminary analysis on the New Zealand sample using both an Enter and Stepwise method. 


\subsection{Model Validation and Hypotheses Testing}

There are two main methods available for model validation, using a holdout sample or the Lachenbruch procedure (Jones, 1987). The former method entails applying the developed model to a new sample of companies not used to derive the model. The Lachenbruch procedure develops a model from $n-1$ observations, and applies it to the observation not used in developing the model. This is repeated until all the firms in the sample are used to assess the model's accuracy. Most importantly, the Lachenbruch method provides an unbiased estimate of the misclassification rate (Jones, 1987). Since the entire sample can be used for cross-validation, this method is useful for use in the corporate failure setting due to the generally small ${ }^{2}$ sample sizes available. Therefore, due to the suitability of the Lachenbruch method in this context, given the relatively small sample size that can be used in New Zealand, it is used to cross-validate the discriminant function.

The hypotheses are tested by comparing the developed models accuracy from the Lachenbruch cross-validation method to Altman's Z-score bankruptcy prediction model which is also applied to the sample of companies used to develop the New Zealand model. Due to the lack of market value information, Altman's modified Z-score model is used with adjusted coefficients (Eidleman, 1995).

\section{Data Analysis}

\subsection{The Model}

The summary discriminant analysis results are shown below in Table 3 . The discriminant analysis on the sample of New Zealand companies using the sixty three independent variables with the stepwise methodology results in a twelve variable discriminant function. These twelve variables coincidently form the optimum discriminant function that maximally discriminates between the failed and non-failed company groups. Out of the 12 variables found to be significant $(p<0.05)$, only three are common to prior studies. These are the Current Assets/Current Liabilities, Total Sales/Average Total Assets and Total

\footnotetext{
${ }^{2}$ For example Grant et al., (1998) developed their model using 17 bankrupt companies and validated it by using 15 companies. Lau (1987) also used a very small sample size of 15 companies.
} 
Liabilities/Total Assets ratios. The remaining eight ratios have not been found to be significant in previous bankruptcy prediction research and are therefore unique to this study.

The tolerances for the model at the final step of variable entry are all above 0.001 indicating that the variables in the discriminant function are not highly dependent or correlated with other variables in the function. The canonical correlation is $54.5 \%$ and $100 \%$ of the variance is explained by the discriminant function. A high Chi-square value which is statistically significant at $p<0.05$ indicates that the discriminant function classifies well.

Table 3

Discriminant Function Summary Statistics

\begin{tabular}{|c|c|c|c|c|c|c|}
\hline Step & \multicolumn{2}{|c|}{ Entered Variable } & $\begin{array}{l}\text { Unstandardised } \\
\text { Canonical Discriminant } \\
\text { Function Coefficients }\end{array}$ & $\begin{array}{l}\text { Wilks' } \\
\text { Lambda }(\lambda)\end{array}$ & $\begin{array}{l}\text { Tolerance } \\
\text { at Step } 12\end{array}$ & Sig \\
\hline 1 & \multicolumn{2}{|c|}{ Total Sales/Total Tangible Assets } & 3.298 & 0.952 & 0.051 & 0.017 \\
\hline 2 & \multicolumn{2}{|c|}{ Quick Assets/Total Assets } & -3.920 & 0.903 & 0.673 & 0.003 \\
\hline 3 & \multicolumn{2}{|c|}{ Current Assets/Current Liabilities } & 0.163 & 0.875 & 0.566 & 0.002 \\
\hline 4 & \multicolumn{2}{|c|}{ Total Sales /Average Total Assets } & -2.671 & 0.847 & 0.051 & 0.001 \\
\hline 5 & \multicolumn{2}{|c|}{ Net income/Average Total Assets } & 5.030 & 0.801 & 0.232 & 0.000 \\
\hline 6 & \multicolumn{2}{|c|}{ Total Liabilities/Total Assets } & 3.654 & 0.775 & 0.167 & 0.000 \\
\hline 7 & \multicolumn{2}{|c|}{ Net Income/Shareholders Funds } & -0.119 & 0.760 & 0.829 & 0.000 \\
\hline 8 & \multicolumn{2}{|c|}{ Working Capital/Total Sales } & 0.023 & 0.746 & 0.936 & 0.000 \\
\hline 9 & \multicolumn{2}{|c|}{ Sales/Average Accounts Receivable } & 0.005 & 0.732 & 0.970 & 0.000 \\
\hline 10 & \multicolumn{2}{|c|}{ Sales/Average Working Capital } & -0.002 & 0.722 & 0.968 & 0.000 \\
\hline 11 & \multicolumn{2}{|c|}{ Net Income/Total Liabilities } & -0.425 & 0.713 & 0.263 & 0.000 \\
\hline 12 & \multicolumn{2}{|c|}{ Shareholders Funds/Total Assets } & 1.727 & 0.704 & 0.196 & 0.000 \\
\hline & \multicolumn{2}{|l|}{ Constant } & -2.786 & & & \\
\hline \multicolumn{7}{|c|}{ Eigenvalues } \\
\hline \multicolumn{2}{|c|}{ Function } & Eigenvalue & $\%$ of Variance & Cumulative \% & \multicolumn{2}{|c|}{ Canonical Correlation } \\
\hline \multicolumn{2}{|c|}{1} & $.421(\mathrm{a})$ & 100.0 & 100.0 & \multicolumn{2}{|c|}{.545} \\
\hline \multicolumn{7}{|c|}{ Wilks' Lambda } \\
\hline \multicolumn{2}{|c|}{ Test of Function(s) } & Wilks' Lambda & Chi-square & df & \multicolumn{2}{|c|}{ Sig. } \\
\hline \multicolumn{2}{|r|}{1} & .704 & 38.685 & 12 & \multicolumn{2}{|c|}{.000} \\
\hline
\end{tabular}

Table 4 shows the results of the Lachenbruch cross-validation procedure. Lachenbruch crossvalidation involves developing a discriminant function from all companies in the sample except for one which used to validate the function. This procedure is repeated until all the companies in the sample have been used as a held-out company. The Lachenbruch classification results show that 36 percent of non-failed companies and 92 percent of failed companies are correctly identified. This is a robust performance given that the function correctly classified 38 percent and 92 percent respectively for the original cases. The model has a Type 1 error of only 8 percent and a Type 2 error of 64 percent. The very high accuracy 
for predicting failed companies and lesser accuracy for non-failed companies is consistent with prior research (Mutchler 1985; Koh and Killough, 1990, Morris, 1997). Since Type 1 errors are agued to be the most costly to auditors, the model's Type 1 error rate of only 8 percent shows its usefulness as an analytical technique for assessing going concern.

Table 4

Lachenbruch Classification Results

\begin{tabular}{|c|c|c|c|c|c|}
\hline \multirow{2}{*}{\multicolumn{3}{|c|}{ STATUS }} & \multicolumn{2}{|c|}{ Predicted Group Membership } & \multirow{2}{*}{ Total } \\
\hline & & & .00 & 1.00 & \\
\hline \multirow{4}{*}{ Original } & \multirow{2}{*}{ Count } & .00 & 19 & 31 & 50 \\
\hline & & 1.00 & 7 & 78 & 85 \\
\hline & \multirow{2}{*}{$\%$} & .00 & 38.0 & 62.0 & 100.0 \\
\hline & & 1.00 & 8.2 & 91.8 & 100.0 \\
\hline \multirow{4}{*}{ Cross-validated } & \multirow{2}{*}{ Count } & .00 & 18 & 32 & 50 \\
\hline & & 1.00 & 7 & 78 & 85 \\
\hline & \multirow{2}{*}{$\%$} & .00 & 36.0 & 64.0 & 100.0 \\
\hline & & 1.00 & 8.2 & 91.8 & 100.0 \\
\hline \multicolumn{6}{|c|}{ Type 1 error: $8.2 \%$ Type 2 error: $64 \%$} \\
\hline
\end{tabular}

\subsection{Altman's Z-score Model}

Altman's model was applied to the same sample of companies used to develop the liquidation prediction model and comprises of five ratios, namely: Working Capital/Total Assets, Retained Earnings/Total Assets, EBIT/Total Assets, Book Value of Equity/Book Value of Debt and Sales/Total Assets. The results of Altman's Z-score model are shown below in Table 5. Altman's model correctly classifies company failures 41 percent of the time and correctly classifies non-failed companies 54 percent of the time. This results in a Type 1 error rate of 59 percent and a Type 2 error rate of 46 percent.

Table 5

Altman's Z-score Model Accuracy

\begin{tabular}{|l|c|c|c|c|}
\hline \multirow{2}{*}{$\begin{array}{l}\text { Actual } \\
\text { Membership }\end{array}$} & Failed & Non-failed & Total & \% accuracy \\
\cline { 2 - 5 } & 23 & 27 & 50 & $\mathbf{5 4}$ \\
\hline Non-failed & 35 & 50 & 85 & $\mathbf{4 1}$ \\
\hline Failed & \multicolumn{2}{|c|}{ Type 1 error: 59\% Type 2 error: 46\% } \\
\hline
\end{tabular}




\subsection{Hypotheses Tests}

The results support Hypothesis 1 that a liquidation prediction model outperforms a bankruptcy prediction model in discriminating between liquidated and continuing companies. The developed company failure model for New Zealand companies was 92 percent successful in predicting company failures compared to Altman's Z-score model accuracy of 41 percent.

Due to differences in debtor and creditor oriented insolvency frameworks among various countries, this finding has significant implications on the choice of corporate failure model that is more appropriate for assessing going concern. Essentially, a non-going concern in a debtor oriented insolvency framework has the opportunity to reorganise and continue operations when the same company would have been liquidated in a creditor oriented insolvency framework.

For debtor oriented countries such as the US where much of previous corporate failure research has taken place, bankruptcy prediction models might still be of value since the US bankruptcy code is designed to keep companies as going concerns (Franks et al., 1996). A liquidation prediction model would not be suitable in this context since bankrupt companies can emerge from bankruptcy as a going concern. However, for countries where the insolvency procedures are creditor oriented, such as in the UK, Germany, Australia and New Zealand, liquidation is the more likely outcome of insolvency (Kaiser, 1996; Franks et al., 1996). In the latter mentioned countries, creditors can obtain control of the company and has the legal right to recover their debt even though it results in the debtor companies' liquidation (Kaiser, 1996; Franks et al., 1996). This suggests that liquidation prediction models are better proxy for assessing going concern in countries where the insolvency laws are creditor oriented.

Hypothesis 2, that the Type 1 errors are lower for the liquidation prediction model compared to the bankruptcy prediction model, is also supported. It shows that the liquidation prediction model correctly classified a failing company 92 percent of the time compared to Altman's bankruptcy prediction model's accuracy of 41 percent. This result in a Type 1 error rate for the liquidation prediction model of only 8 percent compared to Altman's Type 1 error rate of 59 percent. Given that Type 1 errors are most expensive to auditors (Koh, 1991; Carcello and Palmrose, 1994; Geiger et al., 1998), it shows that the liquidation prediction model is a better analytical tool for the auditor for assessing going concern. 
Hypothesis 3 is rejected since the developed model has a higher Type 2 error rate of 64 percent compared to Altman's Type 2 error rate of 46 percent. Prior bankruptcy research also show that corporate failure models generally have high Type 2 errors compared to Type 1 errors (Koh and Killough, 1990, Morris, 1997). The liquidation prediction model correctly classified non-failed companies 36 percent of the time compared to Altman's 54 percent accuracy. This indicates that Altman's model is better at predicting non-failures compared to the developed liquidation prediction model.

The above findings confirm the liquidation prediction model's accuracy over Altman's benchmark bankruptcy prediction model in classifying between liquidated and continuing companies. The liquidation prediction model is more accurate in predicting company liquidation with an accuracy of 92 percent. Given the high costs associated with misclassifying failing companies, this suggests that the developed model can be used as a valuable analytical tool to assist the auditor in forming the going concern judgment.

Furthermore, the findings of this study also raise the issue of the appropriateness of using bankruptcy prediction models in countries where the insolvency code is essentially creditor oriented. In countries such as the UK, Australia and New Zealand, a liquidation prediction model is likely to be more appropriate because the majority of insolvent companies are liquidated, and not given the opportunity of remaining as a going concern as encouraged by the US Chapter 11 insolvency procedures.

\section{Summary and Conclusions}

This study developed and tested the efficiency of a liquidation prediction model against Altman's benchmark bankruptcy prediction model based on the premise that company liquidation is a better proxy for assessing the validity of the going concern assumption than corporate bankruptcy. The developed corporate liquidation model was found to outperform Altman's bankruptcy prediction model in predicting company liquidation. This finding is significant given that Altman's model is a proven model and has been used to benchmark the performance of newly developed corporate failure models (Holmen, 1988; Eidleman, 1995). The Type 1 error of only 8 percent for the New Zealand model is very important given the large costs associated with not qualifying a failing company (Koh, 1991). Furthermore, the going concern status of a company is more likely to be called into question for companies in 
financial distress rather than for healthy companies (Foster, et al., 1998). Hence, the New Zealand model's accuracy of 92 percent in classifying failed companies is especially significant given that the model was developed from failed and stressed companies rather than failed and healthy bankrupt companies as used in prior studies. Consistent with prior research, Type 2 errors remain relatively high compared to Type 1 errors (Mutchler 1985; Koh and Killough, 1990, Morris, 1997).

This research therefore shows that a company liquidation model can be used as a valuable audit tool in assessing going concern due to its very high accuracy with low Type 1 errors. Given the argument that company liquidation is a more appropriate proxy for a company's non-going concern status, this finding is especially important. As a result, future research should be directed at assessing the efficiency of corporate liquidation prediction models as an analytical tool for auditors. This line of research is useful given that bankruptcy prediction models developed in countries where the insolvency law is debtor oriented may not be appropriate for use in countries where the insolvency laws are essentially creditor oriented, such as in the UK, Australia and New Zealand.

Furthermore, previous research has made inferences between auditor accuracy and statistical models' accuracy based on prior audit opinions. Future research should more actively seek to address how useful are statistical corporate failure models for auditors in the actual decisionmaking environment and in different insolvency frameworks, which have not been addressed in prior accounting and auditing research. 


\section{References}

AICPA. (1988). Analytical Procedures. Statement on Auditing Standards No. 56. New York: AICPA.

AICPA. (1988). The Auditor's Consideration of an Entity's Ability to Continue as a Going Concern. Statement on Auditing Standards No. 59. New York: AICPA.

Alderson, M. J., and Betker, B. L. (1999). Assessing Post-Bankruptcy Performance: An Analysis of Reorganised Firms' Cash Flows. Financial Management, 28(2), 68-82.

Alderson, M. J., and Betker, B. L. (1996). Liquidation Costs and Accounting Data. Financial Management, 25(2), 25-36.

Allen, D. E., and Chung, J. (1998). A Review of Choice of Model and Statistical Techniques in Corporate Distress Prediction Studies. Accounting Research Journal, 11(1), 245269.

Altman, E., and McGough, T. (1974). Evaluation of a Company as a Going Concern. Journal of Accountancy, (December), 50-57.

Altman, E. I. (1968). Financial Ratios, Discriminant Analysis and the Prediction of Corporate Bankruptcy. Journal of Finance, 23(4), 589-609.

Asare, S. K. (1990). The Auditor's Going-Concern Decision: A Review and Implications for Future Research. Journal of Accounting Literature, 9, 39-64.

Auditing Handbook (1999). Analytical Procedures: ASB Auditing Standard AUS 512. Prentice Hall: Sydney.

Auditing Handbook (1999). Going Concern. ASB Auditing Standard AUS 708. Prentice Hall: Sydney.

Auditing Practices Board. (1994). The Going Concern Basis in Financial Statements. Statements of Auditing Standards 130. London: APB.

Barnes, P., and Huan, H. D. (1993). The Auditor's Going Concern Decision: Some UK Evidence Concerning Independence and Competence. Journal of Business Finance and Accounting, 20(2), 213-228.

Beaver, W. H. (1966). Financial Ratios as Predictors of Failure. Journal of Accounting Research, 4, 71-127.

Bertoneche, M., and Knight, R. (2001). Financial Performance (1 ed.). Oxford: ButterworthHeinemann.

Betker, B. L. (1996). The Administrative Costs of Debt Restructurings: Some Recent Evidence. Financial Management, 26(4), 56-68.

Blocher, E., and Loebbecke, J. K. (1993). Research in Analytical Procedures: Implications for Establishing and Implementing Auditing Standards. Jersey City: AICPA. 
Boritz, J. E., and Kralitz, E. R. (1987). Reporting on Condition: Auditing the Going-Concern Assumption. CA Magazine, (March), 67-70.

Carcello, J. V., and Palmrose, Z. V. (1994). Auditor Litigation and Modified Reporting on Bankrupt Clients. Journal of Accounting Research, 32, 1-38.

Casterella, J. R., Lewis, B. L., and Walker, P. L. (2000). Modelling the Audit Opinions Issued to Bankrupt Companies: A Two-stage Empirical Analysis. Decision Sciences, $31(2), 507-530$.

Chatterjee, S., Dhillon, U. S., and Ramirez, G. G. (1996). Resolution of Financial Distress: Debt Restructurings via Chapter 11, Prepackaged Bankruptcies, and Workouts. Financial Management, 25(1), 5-18.

Chen, K. C. W., and Church, B. K. (1992): Default on Debt Obligations and the Issuance of Going-Concern Options. Auditing: A Journal of Practice and Theory, 11(2), 30-49.

Collins, R. A., and Green, R. D. (1982). Statistical Methods for Bankruptcy Forecasting. Journal of Economics and Business, 34, 349-354.

Commission on Auditors' Responsibilities: Report Conclusions and Recommendations. (1978). AICPA: New York.

Constable, J. J., and Woodliff, D. R. (1994). Predicting Corporate Failure Using Publicly Available Information. Australian Accounting Review, 4(1), 13-27.

Cormier, D., Magnan, M., and Morard, B. (1995). The Auditor's Consideration of the Going Concern Assumption: A Diagnostic Model. Journal of Accounting, Auditing and Finance, 10(2), 201-221.

Eidleman, G. J. (1995). Z Scores - A Guide to Failure Prediction. CPA Journal, (February), $52-53$.

Foster, B. P., Ward, T. J., and Woodroof, J. (1998). An Analysis of the Usefulness of Debt Defaults and Going Concern Opinions in Bankruptcy Risk Assessment. Journal of Accounting, Auditing and Finance, 13(3), 351-367.

Franks, J. R., Nyborg, K. G., and Torous, W. N. (1996). A Comparison of US, UK, and German Insolvency Codes. Financial Management, 25(3), 86-101.

Geiger, M., Raghunandan, K., and Rama, D. (1998). Costs Associated with Going Concern Modified Audit Opinions: An Analysis of Auditor Changes, Subsequent Opinions, and Client Failures. Advances in Accounting, 16, 117-139.

George, D., and Mallery, P. (2001). SPSS for Windows: Step by Step (3 ed.). Needham Heights: Allyn and Bacon.

Gilbert, L. R., Menon, K., and Schwartz, K. B. (1990). Predicting Bankruptcy for Firms in Financial Distress. Journal of Business Finance and Accounting, 17(1), 161-171.

Grant, T. C., Wheeler, S. W., and Ciccotello, C. S. (1998). Predicting Financial Distress: Audit Classification in a Litigious Environment. Advances in Accounting, 16, 163193. 
Guy, D. M., and Carmichael, D. R. (2000). Practitioner's Guide to GAAS 2000 (1 ed.). New York: John Wiley and Sons.

Holmen, J. S. (1988). Using Financial Ratios to Predict Bankruptcy: An Evaluation of Classic Models Using Recent Evidence. ABER, 19(1), 52-63.

IFAC. (2000). Going Concern. International Standards on Auditing No. 570. Available online: http://www.ifac.org/members.

Institute of Chartered Accountants of New Zealand. (1998). Analytical Procedures. Auditing Standard No. 504. Wellington: ICANZ.

Institute of Chartered Accountants of New Zealand. (1998). Going Concern. Auditing Standard No. 520. Wellington: ICANZ.

Johnson, V. E., and Khurana, I. K. (1993). Companies in Trouble: What Are the Auditor's Responsibilities? Journal of Commercial Lending, 76(4), 52-57.

Jones, F. L. (1987). Current Techniques in Bankruptcy Prediction. Journal of Accounting Literature, 6, 131-164.

Kaiser, K. M. J. (1996). European Bankruptcy Laws: Implications for Corporations Facing Financial Distress. Financial Management, 25( 3), 67-85.

Kennedy, D. B., and Shaw, W. H. (1991). Evaluating Financial Distress Resolution Using Prior Audit Opinions. Contemporary Accounting Research, 8(1), 97-114.

Kertz, J. E., Doogar, R. K., and Jensen, D. E. (1990). A Cross-industry Analysis of Financial Ratios (1 ed.). Westport: Quorum Books.

Koh, C. K. (1991). Model Predictions and Auditor Assessments of Going Concern Status. Accounting and Business Research, 21(84), 331-338.

Koh, H. C., and Brown, R. M. (1991). Probit Predictions of Going and Non-going Concerns. Managerial Auditing Journal, 6(3), 18-23.

Koh, H. C., and Killough, L. N. (1990). The Use of Discriminant Analysis in the Assessment of the Going Concern Status of an Audit Client. Journal of Business Finance and Accounting, 17(2), 179-192.

Koh, H. C., and Oliga, J. C. (1990). More on AUP17 and Going Concern Prediction Models. Australian Accountant, (October), 67-72.

Lau, A. (1987). A Five-state Financial Distress Prediction Model. Journal of Accounting Research,(Spring), 127-138.

Levitan, A. S., and Knoblett, J. A. (1985). Indicators of Exceptions to the Going Concern Assumption. Auditing: A Journal of Practice and Theory, 5(1), 26-39.

Loftus, J., and Miller, M. C. (2000). International Developments on Reporting Going Concern Uncertainties and Financial Vulnerability. Advances in International Accounting, 13, 23-57. 
Louwers, T.J., Messina, F.M., and Richard, M.D. (1999). The Auditor's Going Concern Disclosure as a Self-Fulfilling Prophecy: A Discrete Time Survival Analysis. Decision Sciences, 30(3), 808-824.

Morris, R. (1997a). Early Warning Indicators of Corporate Failure: A Critical Review of Previous Research and Further Empirical Evidence. Aldershot: Ashgate.

Mutcher, J. F. (1985). A Multivariate Analysis of the Auditor's Going Concern Opinion Decision. Journal of Accounting Research, 23(2), 668-682.

Nasir, M. L., John, R. I., Bennett, S. C., Russell, D. M., and Patel, A. (2000). Predicting Corporate Bankruptcy using Artificial Neural Networks. Journal of Applied Accounting Research, 5(3), 30-52.

Schultz, S. M. (1995). Financial Reporting for Firms in Chapter 11 reorganisation. National Public Accountant, 40(1), 24-28.

Wallace, W. A. (1983). The Acceptability of Regression Analysis as Evidence in a Courtroom: Implications for Auditors. Auditing: A Journal of Practice and Theory, 2(2), 66-90.

Woelfel, C. J. (1994). Financial Statement Analysis: The Investor's Self-Study Guide to Interpreting and Analyzing Financial Statements (Revised Edition ed.). Chicago: Probus.

Zhang, M., and Harrold, S. (1997). Going, Going...Gone? Is a GCQ a Self-fulfilling Prophecy? Australian Accountant, (August). Available online: http://www.cpaonline.com.au/Archive/9708/pg_aa9708_goinggone.htm 